\title{
Longitudinal research and early years policy development in the UK
}

\author{
Edward Melhuish ${ }^{1,2,3^{*}}$ (1)
}

\author{
${ }^{*}$ Correspondence: \\ e.melhuish@bbk.ac.uk \\ ${ }^{1}$ University of Oxford, Oxford, \\ UK \\ Full list of author information \\ is available at the end of the \\ article
}

\begin{abstract}
Interest in early years issues such as early childhood education and care (ECEC) and early intervention has increased in recent decades internationally. Partly this reflects interest in facilitating the social and educational development of children, both for deprived children and the general population, and partly interest in increasing parental, particularly maternal, employment. Concern for such issues has led to substantial policy change in the UK in recent decades. For the general population, prior to 1998 there was no statutory obligation for the state to provide any early childhood services for children under the statutory school age of 5 years. However, there were provisions for 'at risk' children, as well as in some nursery education for 3- and 4-year olds, typically in more disadvantaged areas, but availability was haphazard around the country. Research evidence and social and political factors have resulted in radical change to the whole early years services system in the UK. The findings of two longitudinal research studies, the national evaluation of Sure Start and the effective provision of pre-school education projects were important factors in policy change and this paper discusses how the interplay of research and policy occurred. Initially changes were introduced by the Labour government, but more recent policy changes have been introduced by the Conservative government. The need for state involvement in early years services has become accepted by all political parties. There is substantially greater government investment in the early years, so that government-funded ECEC is now part of the infrastructure supporting family life for the whole population. This article discusses how research evidence has contributed to the substantial policy change in the last two decades.
\end{abstract}

\section{Background}

In a changing world the skills that children need for good life chances are increasing and becoming more complex. However, there are great differences in the health and development linked to social origins. Many studies present a consistent picture that adversity in early life is linked to: poor adult mental and physical health, mortality, anti-social and criminal behaviour, substance abuse and poor literacy and academic achievement. Children from poor families are less likely to be successful in school and are more likely to have poorer health and to engage in crime and other problem behaviour later in life (Holzer et al. 2007). However, despite several decades of social, educational and public health reform, the impact of social origins on child outcomes and well-being persists and is even increasing. Also interest in early years issues such as early childhood education 
and care (ECEC) and early intervention has increased in recent decades internationally. Partly this reflects interest in facilitating the social and educational development of children, and partly interest in increasing maternal employment. Inter-related issues are changes in household composition, rising female employment, increasing lone parenthood, reconciling parental, family and work responsibilities, and the need for good social and educational development for children. In such changing times, what should be the role of the state? The supply and financing of early years services is largely determined by government policies and varies between countries.

Concern for such issues has led to substantial policy change in the UK in recent decades. A former leading government official (Eisenstadt 2011) dealing with these issues wrote that the findings of two longitudinal research studies, the National Evaluation of Sure Start (NESS) and the effective provision of pre-school education (EPPE) projects were important factors in policy change. This paper will elucidate how the interplay of research and policy occurred.

\section{The policy context in the UK}

The Labour government that came to power in 1997 had social justice as a priority and economic conditions were favourable. Hence the Treasury commissioned a report on improving outcomes for children from deprived backgrounds (HMT 1998) that led to the Sure Start initiative. Sure Start was designed to improve the development and wellbeing of young children and their families living in disadvantaged areas. Programmes were intended to bring together health, education and social welfare services at neighbourhood level for all families living in the area with children 0-4 years. Local Sure Start programmes had a high level of autonomy that led to a great diversity of approaches across the country. Similar concerns with improving child outcomes in the long-term, particularly for children from deprived backgrounds, led to interest in research on ECEC.

The post 1945 UK welfare state had a clear gender differentiated model of family life, in which men were bread-winners and women were full-time carers, with women and children financially dependent upon men. This dominant ideology started to change gradually after the 1960s, and the advance of feminism and increases in maternal employment and dual-earner households, particularly in the 1980s were driving this change. In parallel attitudes towards, and demand for, early childcare changed. These changes accelerated during the 1980s and 1990s and led to expansion in private childcare provision. The number of places with childminders expanded greatly, almost doubling 1989 and 1997 (from 186,500 to 365,000), and the increase in places in private day nurseries nearly quadrupled (from 46,500 to 173,500) (Department of Health 1997), so that by 1997 a large demand for ECEC was evident and consequently, with no state support, a substantial sector of private for-profit childcare centres had emerged.

\section{Early childhood education and care (ECEC) in the UK}

Early childhood education and care (ECEC) in the UK is a mixed economy, in that it is partly financed and organised by the central and local government, partly by private individuals and organisations, and partly by voluntary organisations (e.g., community groups, charities). ECEC in England includes a wide range of services. Formal provision 
includes day nurseries, nursery schools, nursery classes, playgroups, children or family centres and childminders. Informal provision includes grandparents, friends and neighbours, nannies or other home carers. This list details the range of provision available:

Day nursery

Playgroup (preschool)

Nursery class

Nursery school

Children's centre

Childminders (family day care)

Home carers

Reception class

Childcare for school-children centre-based provision for children under 5 years usually part-time, for children between 2 and 4 years class in primary school for 3- to 4-year olds, mostly part-time

separate pre-school for 3-year olds to start of primary school

multi-purpose facility for children and families, including ECEC $0-5$ years sometimes, and family support and possibly other services

family day care for all ages

family, neighbour, friend; nannies

first year of primary school, may take 4-year olds out-of-school care; group or individual.

Nursery schools, nursery classes, children's centres, and reception classes are all in the public sector. Some playgroups and some day nurseries may also be local government funded, but most are in the private or community sector. Other forms of provision are in the private or community sector.

Essentially prior to 1998 there was no statutory obligation for the state to provide any early childhood education or childcare for children under the statutory starting school age of 5 years. However, there was provision such as local authority day nurseries catering for 'at risk' children, and nursery schools and nursery classes for 3- and 4-year olds, typically in more disadvantaged areas. These services were provided at the discretion of individual local authorities and hence availability was haphazard around the country. Outside the public sector, some children used private fee-paying nursery schools and classes, and many attended voluntary sector playgroups, which often kept fees low by using volunteers. Full-time paid day-care was also available from the private sector. Voluntary and private provision was regulated according to the criteria within the 1989 Children act and from 2005 by the Office for Standards in Education, Children's Services and Skills (Ofsted).

From the mid-1990s ECEC started to re-emerge on the policy agenda. This move to greater priority for state involvement in early childhood education and care has gradually (if fitfully) gathered momentum over recent decades. The key policy changes in recent decades up to the present are shown below:

Children Act reiterated that public funding for childcare should be targeted at families in need. Also it established criteria for regulation of early education and childcare.

1994 A pilot voucher scheme for part-time nursery for 3- and 4-year olds was funded and was piloted over the next few years in a limited range of local authorities.

1995 A duty was placed on Local Authorities to provide services for children in need.

1997 A Labour Government elected and ECEC moves up the policy agenda. 
1998

1999

2000

2002

2003

2003-2006

2004

2005
Comprehensive spending review (HMT Treasury 1998) provides the basis for the Sure Start programme. Free part-time nursery education for 4-year olds; Responsibility for childcare moved to the Department for Education and Employment; National Childcare Strategy set out in a Green Paper; Childcare Tax Credit introduced. Unpaid parental leave (13 weeks) and dependent leave introduced. Curriculum guidance for 3 - to 6-year olds introduced; Parental leave extended to 18 weeks.

The first Minister for Children established, and Education department takes responsibility for children's services; 'Every Child Matters' (HMT 2003) published; paid maternity leave increased from 18 to 26 weeks with 26 weeks additional unpaid leave. Paid paternity leave and the right to flexible working started.

Sure Start moves to children's centre model following EPPE and NESS findings.

Children Act assigns local authorities the duty to reduce the outcomes gap between advantaged and disadvantaged groups. Free part-time early education for 3-year olds; 10-year childcare strategy begins.

Education Act introduces Ofsted inspections for early years settings. Early Years Foundation Stage profile introduced as a universal measure of 5-year-old developmental level. Children's workforce strategy published.

Childcare Act assigns the duty to LAs for sufficient childcare and support for providers; also to improve child outcomes and reduce the outcomes gap between advantaged and disadvantaged groups. The early years professional qualification introduced.

Paid maternity leave increased to 9 months post-birth with 3 months unpaid leave. Government announces plan for 3500 children's centres by 2010.

Early Years Foundation Stage becomes statutory framework.

Updated 10-year strategy sets goal of $90 \%$ of 5-year olds to develop well across all areas of Early Years Foundation Stage profile by 2020.

New conservative-led coalition with Liberal support government was elected.

Additions to paternity leave and pay. Government publishes supporting families in the foundation years on support for children and families from pregnancy to 5 years.

Revision of Early Years Foundation Stage, with streamlined Ofsted inspection. A government commissioned review (Nutbrown 2012) makes clear the inadequacies in training of early years staff.

Free part-time ECEC place for 2-year-old children in $20 \%$ most deprived families.

Free part-time ECEC place for 2-year-old children in $40 \%$ most deprived families.

A conservative government was elected.

$15 \mathrm{~h} /$ week free ECEC extended to free $30 \mathrm{~h} /$ week where parent works $16+$ hours weekly.

Early years foundation profile scheduled to be replaced by alternative assessments in the reception class. 
The 1989 Children Act set out the basic regulations for the registration and regulation of all early childhood education and care (ECEC) settings. This formulation of the ECEC regulations within this Act had been influenced by a government-funded longitudinal study undertaken in the 1980s, the London Day Care Project, which had shown how the quality of care in ECEC and home settings was related to children's developmental outcomes, particularly language development (Melhuish and Moss 1988; Melhuish et al. 1990).

The Foundation Stage, which was a national curriculum covering ages 3-5 years was introduced in 2000. In 2008, this was expanded as the Early Years Foundation Stage covering 0-6 years. In the last year of Early Years Foundation Stage, the reception year in primary school, children are rated by teachers on the Early Years Foundation Stage Profile, which is an assessment involving scales for 13 areas of development detailed in a 90-page handbook. These procedures were revised in 2012.

The government stated its aim to upgrade the ECEC workforce in the Children's Workforce Strategy (HM government 2005), and some improvement in the level of qualifications of the ECEC workforce occurred. An ECEC Providers survey (Brind et al. 2011) shows that by 2010 , for the educationally oriented sector for $3-5$ years, about $40 \%$ of staff had a level 6 qualification or higher, i.e., graduate teachers, and about $40 \%$ were at level 3 or below, i.e., assistants. Whereas in the childcare sector, up to $8 \%$ had a level 6 qualification, and about $50 \%$ had a level 3 qualification, with the remainder having level 2 or less. Early Years Professionals started to appear in the workforce, but were under $4 \%$ in 2010. Around $25 \%$ of heads of full-time services had a level 6 qualification (i.e., graduates), with $9 \%$ of supervisors and $2 \%$ of other workers. In summary the workforce is still not well-qualified, even though some improvements have occurred, and a limiting factor has been the increased pay that increased qualifications would require.

These developments in early childhood education and care listed above formed part of a wider programme of reform that emphasises the integration and improvement of services for children and families, including health and family support in addition to education and childcare. The overall aim is to improve child outcomes and to narrow the gap between children who do well and those who do not. This follows a principle of progressive universalism combining universal services with progressively greater support in relation to need. Protecting vulnerable children is paramount as well as ensuring that vulnerable children do not slip through the net. Such aims were expressed in the Every Child Matters framework, and reiterated in later policy documents, and refer to achieving five outcomes for all children: being healthy; staying safe; enjoying and achieving; making a positive contribution; and achieving economic well-being.

This process of ECEC reform has led to increasing public expenditure on ECEC. This can be illustrated by taking public expenditure on childcare and early educational services for children from 3 years of age to the start of school from the bi-annual OECD social expenditure data collection and annual data on education (OECD 2014). However, it only covers expenditure on pre-primary education not on childcare for the under 3s. In order to get a better comparison of childcare support, indicators were adjusted for cross-national differences in the compulsory age of entry into primary school.

Using data from 2009, of the European countries, which include the top seven spends (\% of GDP) in the OECD, only Denmark (2\%), Iceland (1.6 \%), Sweden (1.5 \%), France (1.2 \%), Norway (1.2\%) spend more than the UK (1.1\%), which is equal to Finland 
(1.1\%). Hence the UK is substantially above the average for European and OECD countries in terms of the \%GDP spent on ECEC. In addition, since 2009, which is the year upon which these country comparisons are made, there has been substantial increases in the UK ECEC spend, e.g., the extension of a free part-time ECEC place to 2-year olds in the most deprived $40 \%$ of families in 2013/2014, and by 2017 the $15 \mathrm{~h} /$ week free ECEC place will be increased to $30 \mathrm{~h} /$ week where a parent works $16+\mathrm{h} /$ week.

\section{Methods}

Eisenstadt (2011), who was a lead civil servant in early years policy, has written that there were two large-scale longitudinal studies that have had a strong influence on government policy since 2000 (Eisenstadt 2011). These are the effective provision of preschool education (EPPE, later EPPSE) project (Sylva et al. 2004, 2010, 2014; Melhuish et al. 2008), which had a replication study in Northern Ireland (effective pre-school provision in Northern Ireland, EPPNI) and the National Evaluation of Sure Start impact study (NESS) (Belsky et al. 2008; Melhuish et al. 2010).

\section{EPPE (EPPSE) project (http://www.ioe.ac.uk/research/153.html)}

The effective provision of pre-school education (EPPE) project was originally authorised by the conservative government in 1996 to provide evidence relevant to the pilot voucher scheme for nursery places for 3- to 4-year olds that had been originally authorised in 1994. After the 1997 general election, the new Labour government killed the voucher scheme, but took an interest in the EPPE project as ECEC was a central policy interest of the new government, and they increased the EPPE funding. The longitudinal study started in 1997 and has followed over 3000 children from age 3 years, with retrospective data back to birth. As the children went into primary school the project became the effective pre-school and primary education (EPPE) project, and as the children moved into secondary school it became the effective pre-school, primary and secondary education (EPPSE) project until its end when children were 18 years old. Hence, in its entirety, it constitutes a birth to 18 years longitudinal study. Hereafter, we will refer to it by its latest acronym, EPPSE. It has focused particularly on the effect of different kinds and quality of group-based ECEC provision, age of starting, and hours of attendance.

\section{National evaluation of Sure Start (NESS) (http://www.ness.bbk.ac.uk)}

Sure Start was designed to improve the development and well-being of young children and their families living in disadvantaged areas. It was aimed initially at areas with high levels of child poverty, and the programme was designed to bring together health, education and social welfare services at neighbourhood level for all families living in the area with children 0-4 years. Strong emphasis was given to involving local parents in the design and delivery of the programme to ensure it was relevant to local needs and circumstances, with consequence that programmes were highly variable, and the variation in Sure Start programmes proved a significant challenge for evaluation. The National Evaluation of Sure Start (NESS) was set up in 2001 to evaluate how well Sure Start was meeting its goals. The biggest of NESS was an impact study including both cross-sectional and longitudinal components involving many thousands of children (NESS 2004, 2005, 2008, 2010, 2012; Belsky et al. 2008). 


\section{Results}

\section{Early results from EPPSE}

When children were 3-4 years old their cognitive, language and socio-emotional development was influenced by demographic factors, such as social class and parent education, as frequently found previously. However, a variable called the Home Learning Environment (HLE), derived from parental report of activities in the home, showed a greater association with all measured aspects of development than the demographic factors. This finding was summarised as "What parents do is more important than who parents are" (Melhuish et al. 2001). This reflects the early finding that the HLE had an equal or more powerful effect upon child development than parents' education or social class. The HLE was a measure of learning opportunities provided in the home and its derivation is fully described in Melhuish et al. (2008) and it continued to show powerful effects upon educational and social outcomes as children became older (e.g., Melhuish et al. 2008; Sammons et al. 2015).

When children entered primary school, the EPPSE study (Sammons et al. 2002, 2003) found that:

- Two to three years of high-quality early years education can provide up to 8 months of developmental advantage in literacy-related outcomes compared to children who enter school with no pre-school experience, with similar effects on other cognitive and social outcomes.

- While high-quality ECEC experience provided a boost, the greatest predictor of success was the home learning environment (HLE), i.e., the learning opportunities provided at home had the largest effect on child outcomes.

- The quality of ECEC is correlated with staff qualifications, and higher quality was related to better outcomes for children.

These findings had several effects upon policy. The first was that the government decided to provide a free part-time ECEC place for every child from their third birthday, until the start of school, which came into effect in 2004. Secondly, several government officials and politicians were struck by the power of the effects of the HLE and emphasis on improving the HLE influenced several subsequent decisions on early years provision, including a pilot programme to improve the early years HLE; including the importance of HLE in subsequent ECEC staff training programmes; and using the HLE as an outcome of interest in subsequent programmes. Thirdly, the importance of the quality of ECEC and the role of staff training in developing quality was recognised.

Another finding from the EPPSE project was that a type of ECEC provision called integrated centres was having particularly beneficial effects upon children at the start of school. The centres integrated childcare, early education and often family support and sometimes other family services and they were to become called children's centres.

\section{Results from NESS}

The other influential longitudinal study, the NESS impact study included many thousands of children living in deprived areas that received a Sure Start early intervention programme and a comparison group of children in similarly deprived areas not receiving Sure Start. The initial reports revealed the great variation amongst Sure Start 
programmes with many differing approaches being used (NESS 2002; Melhuish et al. 2007). The children were initially compared cross-sectionally (NESS Research Team 2004). Subsequently, 5883 children from Sure Start areas and 1979 children from nonSure Start areas were followed longitudinally at 9 months, 3, 5 and 7 years of age (NESS 2008, 2010, 2012). The first cross-sectional stage, found that Sure Start was beginning to have positive effects on most of the children, particularly those whose mothers were beyond their teenage years (NESS Research Team 2004; Belsky et al. 2006). These children had greater social competence and fewer behaviour problems, with parents using negative parenting techniques less frequently. It was particularly disappointing, however, that children of teenage parents, or in workless households, or in lone parent households, were not doing as well as their counterparts in non-Sure Start areas. They had lower social competence levels, more behaviour problems and poorer verbal ability. Sure Start seemed to be working for deprived children, but not the most deprived. Also there was great programme variability with some programmes seeming to be effective, but many were ineffective. However, Sure Start was enormously popular with parents.

The NESS evidence of disappointing results for Sure Start programmes together with the EPPSE results showing that integrated children's centres were particularly effective led the Minister for Children to decide that all Sure Start programmes should become children's centres, with a more clearly specified set of services and stronger integration of health, child care, education and parent-support services. This change started in late 2003 and was completed by 2006. This was to profoundly influence the future of the Sure Start initiative, as the researchers effectively became 'policy actors' (Lewis 2011).

The second longitudinal stage of the NESS impact study showed real improvements from Sure Start programmes, which, by this time, were mostly operating the children's centre model (NESS 2008; Melhuish et al. 2008). There was no difference between children of teenage and other mothers and all sections of the population showed improvements, including: positive social behaviour; greater child independence and self-regulation; improvements in home learning environments and parent-child relationships; less harsh parenting; and increased service use. The emergence of these more promising results together with the great popularity of Sure Start programmes amongst parents led to the government's announcement of the intention to have 3500 children's centres by 2010 . While this policy decision was influenced by NESS results, it was not supported by the actual NESS evidence, and this illustrates how politicians will use evidence to suit their own goals rather than following the logic of the evidence itself.

A later stage, when children were 5 years old, continued to show improvements, but this time primarily for child health (lower rates of overweight among the Sure Start children and better general health) and parenting (less home chaos, better home learning environments, mothers reporting greater life satisfaction and reduced worklessness in Sure Start families compared to similar families without Sure Start) (NESS 2010).

Small ongoing improvements in assessments of all 5-year olds in school and, most importantly, a small but significant narrowing of the gap in results between the poorest children and their better-off peers have been seen. Children in the most deprived areas moved from 39 \% working securely in the main areas of learning in 2008 to $47 \%$ by 2010 , while children in other areas moved from 55 to 61 \% (Department for Education 2010). 
While these changes were small, they indicated that a series of policies, including universal provision for 3- and 4-year olds (based on EPPSE evidence) and Sure Start's multiagency approach through children's centres, were beginning to show results at whole-population level and that the poorest children improved at a faster rate over the course of the study, which was relevant for the duty placed on local authorities by the 2004 Children Act to reduce the outcomes gap between disadvantaged and more advantaged children.

The early success of children's centres and their great popularity with parents led to the government's decision in 2007 to pursue 3500 children's centres, which involved around a five-fold increase in the number of children's centres over a 3-year period, but without commensurate increases in funding. This was a policy mistake of pushing for expansion before the systems were ready, or when funding was inadequate. It was followed by the global recession of 2008, with subsequent austerity cuts to public spending, and then followed by the defeat of the Labour government in the 2010 election. All of these factors contributed to the steady decline of children's centres.

\section{Later EPPSE results}

As children in the EPPSE study moved through the school system there was a need to consider the effects of schooling itself as well as the effects of child, parent, home, area and pre-school experience variables, which had been used in the earlier reports. Therefore a measure of the effectiveness of schools was devised from National assessment data for all children in England (Melhuish et al. 2006). For some schools children did better than expected-effective schools and for some schools children did worse than expected-ineffective schools. A continuous measure of academic effectiveness was derived for all primary and secondary schools in England. Using this array of variables an analytic model represented by the following diagram (Fig. 1) was used to plan analyses using hierarchical linear modelling (multi-level modelling).

In such analyses the effects associated with a predictor variable, e.g., pre-school quality, could be estimated after allowing for the effects of all other variables in the model. Using this approach successive stages of the EPPSE project showed the continuing longterm effects of experience in the pre-school period including ECEC experience and the early years HLE, as well as the effects of demographic factors and school effectiveness. When children are 11 years old in England every child takes a national Key Stage 2 assessment. These assessment data were used to analyse the effects of a range of variables upon children's educational and social development. The following graph (Fig. 2) shows the relative size of effects (in standard deviation units) of a range of variables with strong effects upon children's achievement in literacy and numeracy, as measured by National Assessments, at age 11 (Melhuish 2011; Sammons et al. 2008).

Mother's education (effect size $=0.70+$ for literacy and numeracy), and the Home Learning Environment (measured at age $3-4$ ) (effect size $=0.68$ literacy; 0.42 numeracy) are the strongest influences upon children's attainment. However, preschool effectiveness and primary school effectiveness are also important influences and are very similar in their importance and account for about half as much variance as home factors. Note that the effects for going to a high-quality pre-school compared with no pre-school are similar in size to the effects of going to a high effective primary school versus a low effective primary school, yet a child on average had been in the pre-school centre for 


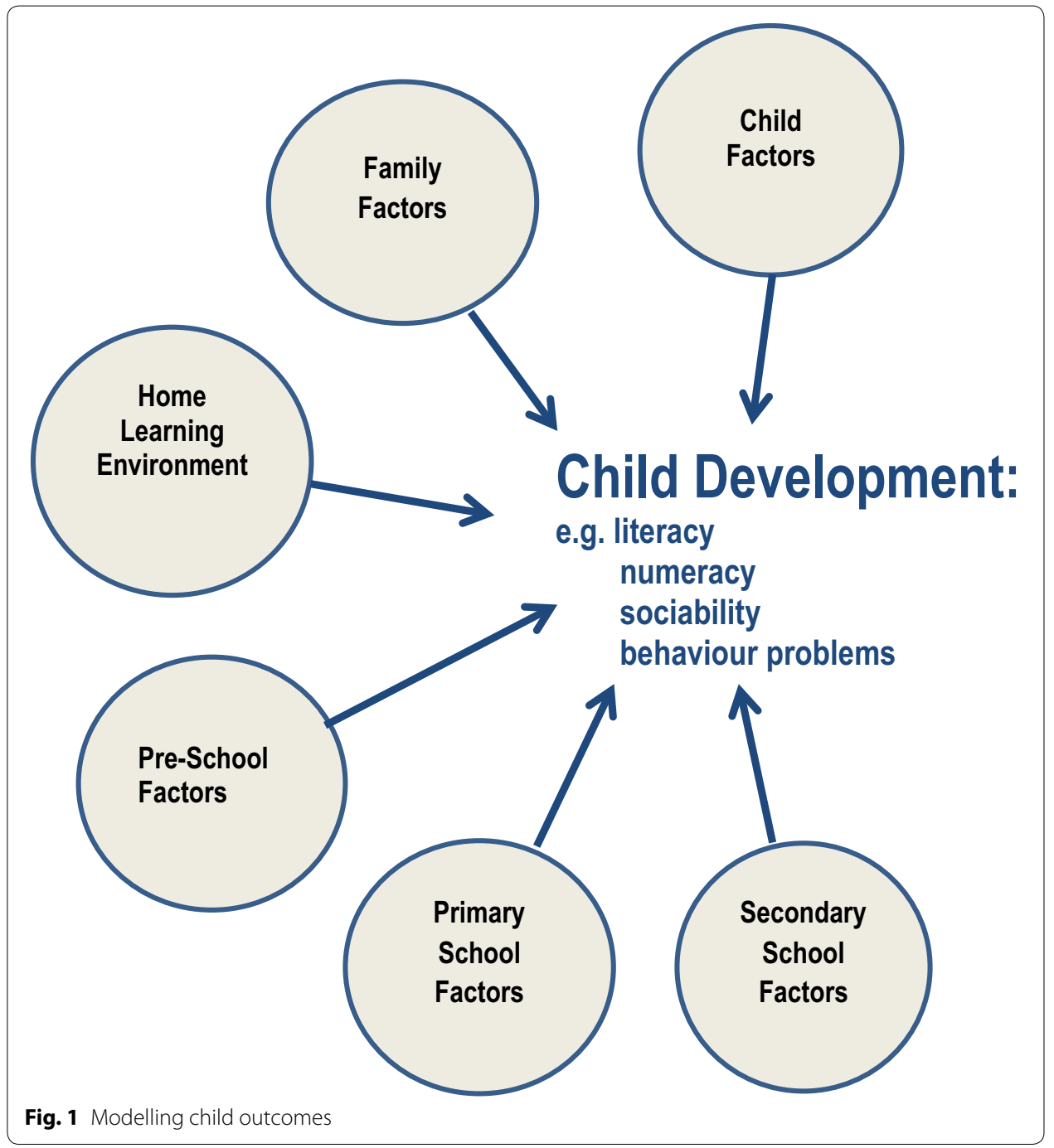

18 months, but had been at primary school for 6 years. While the effects displayed are for attainment in literacy and numeracy, there are also substantial similar effects upon children's social development.

A similar strategy was repeated to analyse the effects of potential predictor variables upon academic or social development at subsequent stages of the EPPSE project at age 14, 16 and 18 years (Sylva et al. 2011; Sammons et al. 2014a, b, 2015) The results for literacy and numeracy at age 16, derived from the national assessments that children take at age 16, are shown in Fig. 3 below.

As at age 11, mother's education is still exerting the strongest effect upon literacy and numeracy, albeit somewhat reduced in size from earlier. Secondary school effectiveness has become a strong effect revealing the enormous diversity in quality and effectiveness amongst secondary schools in England. This huge diversity amongst secondary schools makes the choice (or assignment) of secondary school a critical factor for a child's chances of academic success. Also it is apparent that going to a high-quality pre-school compared to no pre-school is still having an effect upon child outcomes 11 years after 


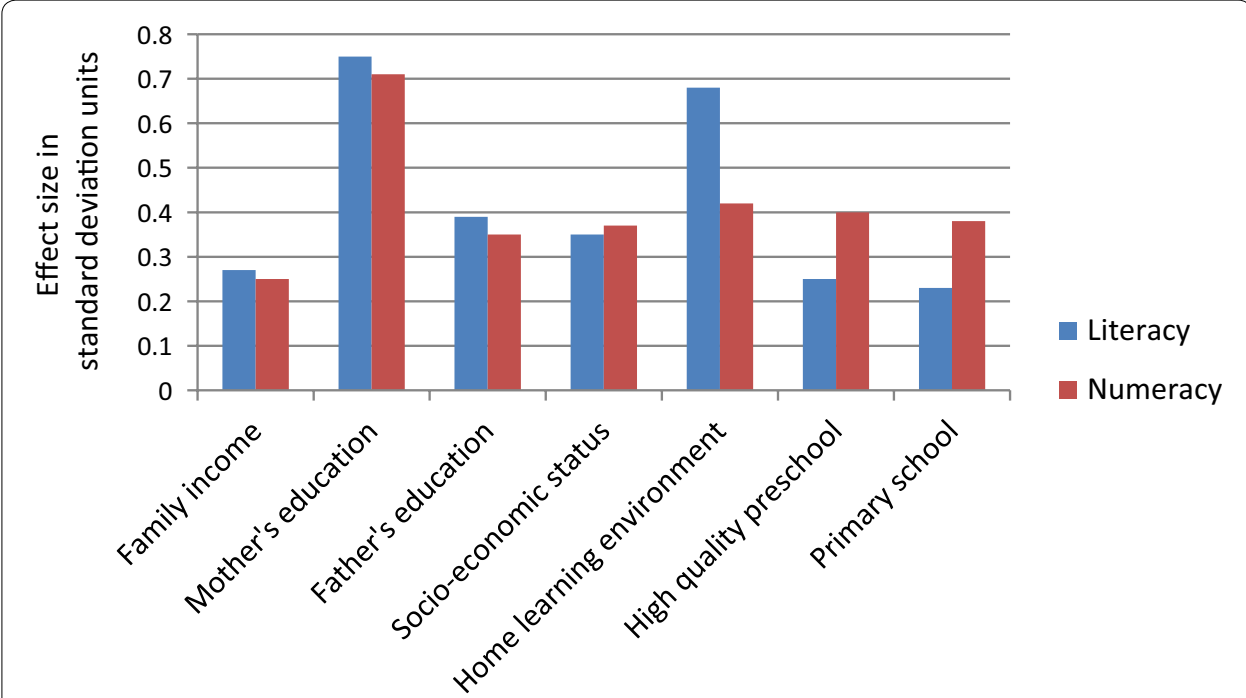

Fig. 2 Effects upon children's literacy and numeracy at age 11 years

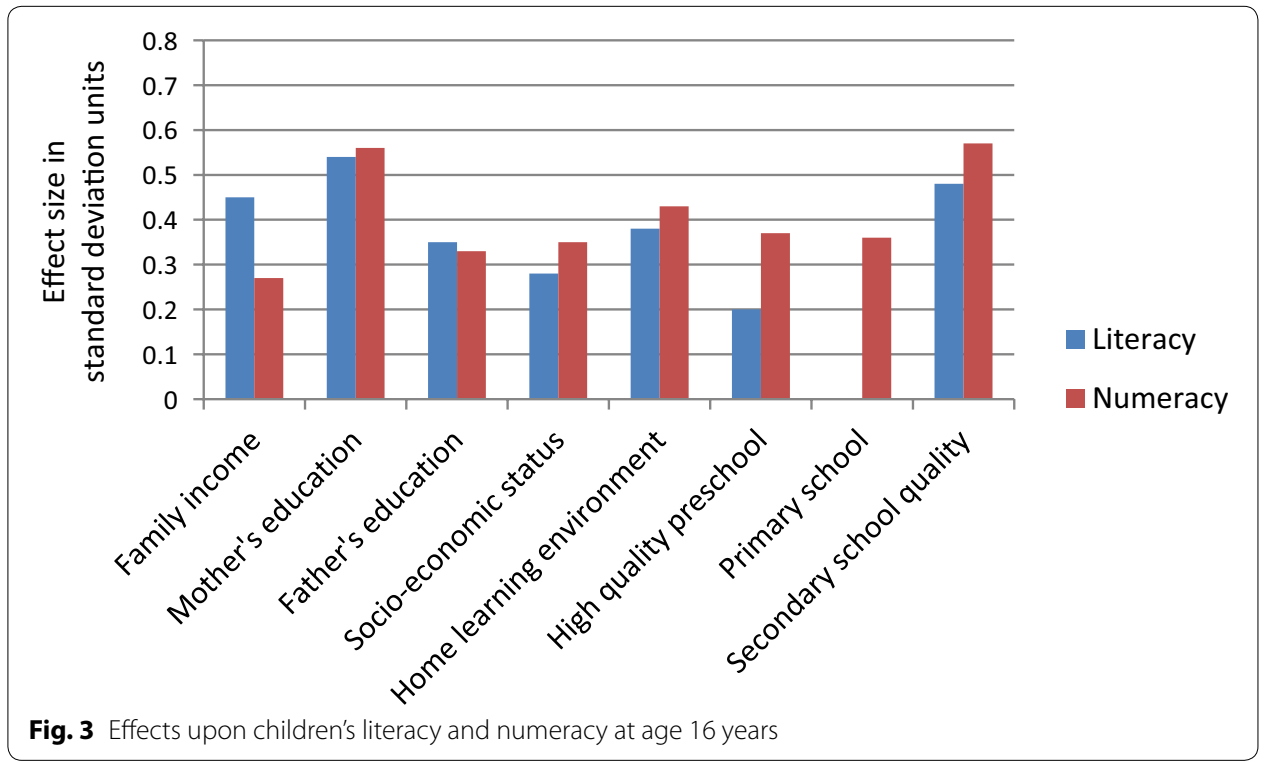

leaving the pre-school. Additionally the effects of the early years (3-4 years old) HLE is still powerful, many years after it was measured. The HLE was measured in later years also and while these later HLE measures did exert some effects it was the early years HLE which exerted the most consistently powerful effects across the age range of the EPPSE study up to age 18 years (Sammons et al. 2015).

The evidence from the EPPSE study was supported by a parallel study using similar methods in Northern Ireland. The Effective Pre-school Provision in Northern Ireland (EPPNI) project (Melhuish et al. 2006, 2010, 2012) was a longitudinal study of child development up to 11 years. It investigated the effects of different kinds of preschool provision, and related experience in preschool to child development. In EPPNI, 683 
children were randomly selected from 80 preschools, and 151 children were recruited without preschool experience. Progress was then followed up to age 11. Preschool experience was related to age 11 performance in English and mathematics. High-quality preschools show consistent effects that are reflected not only in improved attainment in Key Stage 2 English and mathematics but also in improved progress in mathematics over primary school. Children who attended high-quality preschools were 2.4 times more likely in English, and 3.4 times more likely in mathematics, to attain high grades than children without preschool experience. Throughout the study high-quality ECEC experience was found to have benefits for educational and social development, as was found in EPPSE results.

\section{Discussion}

\section{What makes ECEC effective?}

The EPPSE study was able to identify the most effective ECEC centres that produced the most developmental benefit for children. Qualitative case studies of the most effective and average centres investigated what processes were associated with those that were particularly effective. In these case studies (Siraj-Blatchford et al. 2003) the researchers did not know which ECEC centres had been identified as effective or ineffective, so their observations were not biased. These case studies identified 5 areas that were particularly important for effectiveness in ECEC centres.

1. Quality of adult-child verbal interaction.

2. Staff knowledge and understanding of the curriculum.

3. Staff knowledge of how children learn.

4. Adult skills in helping children resolve conflicts.

5. Helping parents to support children's learning at home.

Also in the observations of adult-child interaction in effective ECEC centres a particular kind of interaction called sustained shared thinking was observed. It was not observed in ineffective centres. The term 'sustained shared thinking' was first coined by Siraj-Blatchford et al. (2003) arising from the qualitative analysis of data. Sustained shared thinking involved an adult interacting with two (or more) children in a process of solving an problem or creating something. The adult would structure the situation and provide limited input but enough to facilitate the child's problem-solving or creative activities, so that the child could arrive at a desired goal. Being able to engage in sustained shared thinking with a child was recognised as a key skill of the staff in early childhood settings who were effective in supporting children's socio-emotional and cognitive outcomes. The skills of practitioners in terms of how they interact with children and support their learning and development are central to high-quality provision.

\section{Sustained shared thinking and emotional well-being (SSTEW) scale}

It had become apparent through the experience of the EPPSE and other studies that the established measures of quality of early years provision, as used in many previous studies, were useful in many respects but that they missed out on aspects of staff-child interaction that were likely to be important for the child's longer-term development. Hence 
it was decided to develop new scales that could fill this gap. In particular, the findings from the EPPSE case studies (Siraj-Blatchford et al. 2003) of effective centres were used as the starting point in the development of a new observational measure of quality in ECEC centres. The case studies revealed practitioner behaviours that differentiated the most effective from average centres that were not being measured by existing observational measures of ECEC quality. This led to the development of the instrument that was called the sustained shared thinking and emotional well-being (SSTEW) scale (Siraj et al. 2015), and although originally designed for $2-5$ year olds it has been found to be particularly relevant for provision for children 2-6 years old. Engaging in sustained shared thinking (SST), which includes the successful support of a child's thinking and learning, undoubtedly requires a highly skilled and knowledgeable practitioner. A practitioner who is skilled in assessing, monitoring and supporting children's socio-emotional, linguistic, and cognitive development and who also ensures that the child feels safe, comfortable, interested and stimulated, as these are necessary conditions for the child to be ready to learn (Melhuish 2004) and to be in a position to think deeply. Also the EPPSE study had found that a child's self-regulation abilities at the start of school were very predictive of later educational and social development (Melhuish et al. 2007), and these self-regulation abilities appeared to mediate the effects of high-quality ECEC experience as well as the HLE. Hence the SSTEW scale included activities likely to foster the child's self-regulation abilities.

The developmental domains within SSTEW include social and emotional development as well as cognitive and language development and give rise to the following five sub-scales:

- Building trust, confidence, and independence and

- Social and emotional well-being.

- Supporting and extending language and communication.

- Supporting learning and critical thinking, and

- Assessing learning and language.

While there are important differences in development between children aged 2-6 years, the SSTEW scale focuses on common practices that will support and nurture children within this age range when suitably adapted to the individuals involved.

\section{Further policy influence}

The early EPPSE evidence, which has been repeatedly reinforced by international evidence (Melhuish et al. 2015) influenced the universal provision of a free part-time ECEC place for children from their third birthday, and this has affected the lives of millions of children. It also influenced, together with NESS evidence, the establishment of children's centres. As EPPSE evidence accumulated further policy influence occurred (Taggart et al. 2008). The early child matters from 2003, and the 10 year childcare strategy in 2004 and 2009, contain references to EPPSE evidence that clearly influenced the proposals in these documents, as well as the Nutbrown (2012) review for the government on education and training for the early years workforce. Amongst the government policies influenced by EPPSE was the government's efforts to increase the qualification levels of 
ECEC staff (e.g., children's workforce strategy, 2005; early years Professional qualification, 2006) as EPPSE had shown that quality of provision was related to staff qualifications (Sylva et al. 1999, 2004).

Following the election of a new government in 2010, which had a cost-cutting agenda, the EPPSE evidence was crucial in the decision to maintain spending for the early years. Thus in 2012 this government not only kept existing ECEC provision, but also announced the extension of the free part-time ECEC place down to 2-year olds for children in the $40 \%$ most disadvantaged families, following the EPPSE evidence that highquality ECEC from age 2 years was beneficial (Sammons et al. 2002, 2003; Sylva et al. 2004). The enactment of this policy started in 2013. EPPSE findings are noted by the National Audit Office (2016) as underpinning key decisions by the Department for Education in recent decades to increase the quantity and quality of early education and care.

\section{Study of early education and development (SEED) (http://www.seed.natcen.ac.uk/)}

Politicians and government officials recognised that EPPSE evidence had been extremely useful for the formation of early years policy, so that policy had changed greatly in the years of the EPPSE study. However, the EPPSE sample had been assembled at a time when a very different set of conditions existed, and hence the data were becoming less relevant to the current situation, as a result of the policy changes following EPPSE evidence. Therefore the government decided to set up a new longitudinal study to consider the impact of current early years provision, so that it could inform future policy. A competitive tender was issued for the Study of Early Education and Development (SEED), which started in 2013.

The study of early education and development (SEED, http://www.seed.natcen.ac.uk) is a major longitudinal study that investigates the impact of early childhood education and care on children's school readiness and longer-term outcomes, as well as its impact on the most disadvantaged children. More knowledge is needed about the long-term effects and benefits of early years education, particularly as it is extended to younger children. We still have little knowledge of the long-term cost-benefits and, specifically, how usage and quality affect these. The early years is a key area of social policy and intervention that claims many positive, wide-reaching and long-term outcomes. It is also an area of social policy that continues to undergo rapid change, most notably the widening of access, and the extension of hours.

Early years education is an area of high expenditure for the Department for Education, which spent $£ 1.9$ billion on free early years entitlement in 2010 . Spending was set to increase by $£ 64 \mathrm{~m}$ when entitlement was rolled out to the first groups of eligible 2-year olds. As the roll-out builds year on year, it was estimated to cost an additional $£ 760 \mathrm{~m}$ by 2014/15. The gaps in knowledge need to be addressed in order to gain the best value from this investment. It is regarded as vital by the government that it has objective, robust and impartial information to inform its policy development and spending decisions in this area, as highlighted by the National Audit Office. Fundamental assumptions need to be tested and children's development followed to assess the effect of early years education on their long-term outcomes. Critically, the cost-benefit and value for money of early years intervention needs to be understood. 
SEED is a large-scale longitudinal, mixed methods research study that will:

- Follow the progress of 5000 children from age 2 years until Key Stage 1 (aged 7);

- Assess the quality of 1000 early years settings that they attend;

- Provide examples of best practice through case studies of settings;

- Offer insights into the perspectives and experience of childminders on the free entitlement provision and its extension to 2-year olds through a qualitative study;

- Provide qualitative case studies to show how the needs of children with special educational needs and/or disability are met;

- Quantify and monetise the impacts of early education through a value for money study to specifically monetise outcomes associated with the extension of free early education to disadvantaged children.

To assess the quality of provision for 2-, 3- and 4-year olds SEED has undertaken assessments for 1000 settings using observational scales. The ITERS scale and the new SSTEW have been used for 2-year-old settings, including childminders (Otero and Melhuish 2015) and the ECERS-R, ECERS-E (as in EPPSE) and the SSTEW scales are used for 3- to 4-year-old settings.

The SEED study is still young and only a few publications have emerged. SEED has produced reports on the views and experiences of childminders (Callanan 2014); a baseline survey of families in the longitudinal study when their children are 2 years old Speight et al. (2015); and a study of quality of care amongst childminders working with 2-year olds (Otero and Melhuish 2015). Future reports will consider the main aims of the project.

\section{Conclusions}

The EPPSE research has shown the long-term impact of high-quality ECEC provision. Hence it is important to develop a regulation and inspection system that applies to all settings with young children in early years services. Young children's needs do not differ whether they are in a setting provided by a state-based education agency or a private sector childcare organisation. The standards and requirements of settings should not differ either. Linked to inspection and regulation is the importance of data to ensure the quality of services and child outcomes improve. While debates about the nature of assessment persist, some form of standard assessment around the start of school provides evidence that services are doing what is expected. Without national measures, it is difficult to identify if policies are effective and money is being well spent. All of these aspects of policy require political will. In the case of the UK the EPPSE and NESS studies overlapped with a government that was committed to evidence-based policy, and was open to the findings from research, as it fitted with their political agenda. The study was in the right place at the right time.

However, the research has to be convincing, and for governments quantitative research with large samples tends to be more convincing. Eisenstadt (2011) writes that the EPPSE, EPPNI and NESS research influenced policy because of a number of factors as follows. The research was regarded as being of the highest quality. The high-quality quantitative evidence was particularly important to Treasury, while the qualitative work was seen as important through its underpinning in the quantitative evidence. The researchers were 
willing to participate in a process of discussion and debate that was very different to the typical academic discourse. This includes a willingness to present complex research findings in different ways and to draw out clear and firm policy conclusions and recommendations. Also government's stated commitment to 'evidence-based policy-making' may have attracted researchers to become involved in policy discussions, in the expectation that their work would be taken seriously and make a difference. The relatively healthy state of the economy and the public finances at the time also helped to create an atmosphere that encouraged interest groups and researchers to come forward with new ideas. Research groups such as NESS and EPPE have been willing to engage on a regular basis with the media to discuss and explain their research. Also, flexibility by research teams to respond to changing policy requirements was important. This was helped by the fact that for EPPSE, EPPNI and NESS policy agencies were the primary funders; nonetheless, researchers went beyond contractual obligations to create what can be described as 'co-production' between policy and research interests. Such 'co-production' relies on the existence of government officials, practitioners and indeed politicians who are interested in, and recognise the important of, social research.

As the population grew accustomed to the changes introduced as a consequence of the EPPSE findings, they were reluctant to do without them, and the belief that early years services are part of government responsibilities came to be accepted across the political spectrum. Thus we see the conservative-led governments from 2010 carrying on with the improvement of early years services including ECEC.

Politicians win votes by expanding services: improving early years services is rarely noticed by the public whose taxes pay for improvements, and even by parents who use the services. A conscious decision was made to get a universal infrastructure in place and then focus on quality. The country has largely avoided the poorest quality of provision, which can damage children, through rigorous inspection, but still needs to improve overall quality, and this will require further investment in the workforce. It is important for countries with fewer resources to ensure at least a basic minimum quality. Political will was critical to the developments.

Experience suggests that different parts of government want early years services for different reasons. The Department of Education pushed for universal free part-time ECEC provision because the EPPSE evidence indicated that for the general population of children that part-time was as beneficial as full-time. However, other government departments want to use ECEC to increase parental (particularly maternal) employment, and it was this motivation that has led to the proposed increase in the universal ECEC offer from $15 \mathrm{~h}$ /week to $30 \mathrm{~h} /$ week. Antipoverty strategies should include parental employment but also should include high-quality ECEC as the EPPSE evidence, as well as other research indicates that children from poor families have most to gain from high-quality ECEC (Melhuish et al. 2015), hence it is important to ensure that the ECEC provided for children from poor families is high quality. Employment is critical for reducing child poverty but must be accompanied by quality, affordable child care. The general support of the population is important, and engaging with lobby groups and influential organisations and working with the media all help to drive political support to improve services for young children. Without government support, programmes will be patchy and will fail to reach most children, particularly the children most in need. 


\section{Abbreviations}

ECEC: early childhood education and care; EPPE: effective provision of pre-school education project; EPPSE: effective pre-school, primary and secondary education project; EPPNI: effective pre-school provision in Northern Ireland project; HLE: home learning environment; GDP: gross domestic product; HMT: Her Majesty's Treasury; OECD: Organisation for Economic Cooperation and Development; SEED: study of early education and development; SSTEW: sustained shared thinking and emotional well-being.

\section{Author details}

${ }^{1}$ University of Oxford, Oxford, UK. ${ }^{2}$ Birkbeck University of London, London, UK. ${ }^{3}$ University of Wollongong, Wollongong, Australia.

\section{Competing interests}

The authors declare that they have no competing interests.

Received: 27 April 2016 Accepted: 18 August 2016

Published online: 07 September 2016

\section{References}

Belsky, J., Melhuish, E., \& Barnes, J. (2008). Research and policy in developing an early years initiative: the case of sure start. Int $J$ Child Care Educ Policy, 2, 1-13.

Belsky, J., Melhuish, E., Barnes, J., Leyland, A., Romaniuk, H., \& the NESS Research Team. (2006). Effects of Sure Start local programmes on children and families: early findings from a quasi-experimental, cross-sectional study. BMJ, 332, $1476-1478$

Brind, R., Norden, O., McGinigal, S., Garnett, E., Oseman, D., La Valle, I., Jelicic, H. (2011) Childcare and early years providers survey 2010. London: DfE. https://www.education.gov.uk/publications/eOrderingDownload/OSR17-2011-Main\%20 research\%20report.pdf.

Callanan, M. (2014). Study of early education and development: views and experiences of childminders. London: DfE. http://www.seed.natcen.ac.uk/media/2897/rr395_childcare_provision_views_and_experiences_of_childminders.pdf.

Department for Education. (2010). Early years foundation stage profile results in England, 2009/2010. London: DfE. http:// www.data.gov.uk/dataset/early-years-foundation-stage-profile-results-england-2010@2012-06-27T15\%3A26 $\% 3 \mathrm{~A} 28.769731$.

Department of Health. (1997). Children's day care facilities at 31 March 1997. London: Department of Health.

Eisenstadt, N. (2011). Providing a sure start: how Government discovered early childhood. Bristol: Policy Press.

HM Government. (2005). Children's workforce strategy: a strategy to build a world-class workforce for children and young people. London: DfES. http://www.education.gov.uk/consultations/downloadableDocs/5958-DfES-ECM.pdf.

HMT Treasury. (1998). Modern public services for Britain: investing in reform, comprehensive spending review: new public spending plans, 1999-2002, Cm4011. London: Stationery Office.

HMT Treasury. (2003). Every child matters. London: HMSO. http://www.education.gov.uk/consultations/downloadableDocs/EveryChildMatters.pdf.

Holzer, H.J., Schanzenbach, D.W., Duncan, G.J., \& Ludwig, J. (2007). The economic costs of poverty in the United states: Subsequent effects of children growing up poor. National Poverty Center Working Paper Series 07-04. http://www. npc.umich.edu/publications/working_papers/.

Lewis, J. (2011). From Sure Start to children's centres: an analysis of policy change in English early years programmes. J Soc Policy, 40, 71-88.

Melhuish, E. C. (2004). Child benefits: the importance of investing in quality childcare. London: Daycare Trust.

Melhuish, E. C. (2011). Preschool matters. Science, 333, 299-300.

Melhuish, E. C., \& Moss, P. (1988). Report to the chief scientist. London: DHSS.

Melhuish, E. C., Lloyd, E., Martin, S., \& Mooney, A. (1990). Type of childcare at 18 months: Il Relations with cognitive and language development. J Child Psychol Psychiatry, 31, 861-870.

Melhuish, E. C., Sylva, K., Sammons, P., Siraj-Blatchford, I., \& Taggart, B. (2001). The effective provision of pre-school education project, technical paper 7: social/behavioural and cognitive development at 3-4 years in relation to family background. London: Institute of Education/DfES.

Melhuish, E., Quinn, L., Hanna, K., Sylva, K., Siraj-Blatchford, I., Sammons, P., et al. (2006a). The effective pre-school provision in northern Ireland Project. Summary report. Belfast: Stranmillis University Press.

Melhuish, E., Romaniuk, H., Sammons, P., Sylva, K., Siraj-Blatchford, I., \& Taggart, B. (2006b). Effective pre-school and primary education 3-11 (EPPE 3-11) project. The effectiveness of primary schools in England in key stage 2 for 2002, 2003 and 2004 London: Institute of Education.

Melhuish, E. C., Belsky, J., Anning, A., Ball, M., Barnes, J., Romaniuk, H., et al. (2007a). Variation in Sure Start local programme implementation and its consequences for children and families. J Child Psychol Psychiatry, 48, 543-551.

Melhuish, E.C., Sylva, K., Sammons, P., Siraj-Blatchford, I., Taggart, B., \& Phan, M. (2007). In EPPE (3-11) Team (Eds.) Promoting equality in the early years: report to the equalities review. London: Cabinet Office. http://www.equalitiesreview.org.uk.

Melhuish, E., Belsky, J., Leyland, A. H., Barnes, J., \& Research Team, N. E. S. S. (2008a). Effects of fully-established Sure Start local programmes on 3-year-old children and their families living in England: a quasi-experimental observational study. Lancet, 372, 1641-1647.

Melhuish, E. C., Sylva, K., Sammons, P., Siraj-Blatchford, I., Taggart, B., \& Phan, M. (2008b). Effects of the home learning environment and pre-school center experience upon literacy and numeracy development in early primary school. J Soc Issues, 64, 157-188.

Melhuish, E. C., Sylva, K., Sammons, P., Siraj-Blatchford, I., Taggart, B., Phan, M., et al. (2008c). Preschool influences on mathematics achievement. Science, 321,1161-1162. 
Melhuish, E., Belsky, J., \& Barnes, J. (2010a). Evaluation and value of sure start. Arch Dis Child, 95, 159-161.

Melhuish, E., Quinn, L., Sylva, K., Sammons, P., Siraj-Blatchford, I., \& Taggart, B. (2010b). Pre-school experience and Key stage 2 performance in english and mathematics. Belfast: Dept for Education.

Melhuish, E., Quinn, L., Sylva, K., Sammons, P., Siraj-Blatchford, I., \& Taggart, B. (2012). Preschool affects longer term literacy and numeracy: results from a general population longitudinal study in Northern Ireland. Sch EffSch Improv Int J Res Policy Pract, 24, 234-250.

Melhuish, E., Ereky-Stevens, K., Petrogiannis, K., Ariescu, A., Penderi, E., Rentzou, K., Tawell, A., Slot, P., Broekhuizen, M., Leseman, P. (2015). A review of research on the effects of early childhood education and care (ECEC) upon child development. CARE project; curriculum quality analysis and impact review of European early childhood education and care (ECEC). http://www.ecec-care.org/resources/publications/.

Otero, M.P. Melhuish, E. (2015). Study of early education and development (SEED): study of the quality of childminder provision in England. London: DfE. http://www.seed.natcen.ac.uk/media/5723/RR480B_-_SEED_the_quality_of_childminder_provision_in_England.pdf.

National Audit Office. (2016). Entitlement to free early education and childcare. Report by the Comptroller and Auditor General. London: National Audit Office. https://www.nao.org.uk/wp-content/uploads/2016/03/Entitlement-to-freeearly-education-and-childcare.pdf.

NESS. (2010). The impact of Sure Start local programmes on five year olds and their families: research report DFE-RR067. London: DfE.

NESS Research Team. (2002). Early experiences of implementing sure start. London: DfES. http://www.ness.bbk.ac.uk/implementation/documents/157.pdf.

NESS Research Team. (2004). The impact of Sure Start local programmes on child development and family functioning: report of preliminary findings. London: DfES.

NESS Research Team. (2005). Early impacts of Sure Start local programmes on children and families. Surestart report 13. London: DfES.

NESS Research Team. (2008). The impact of Sure Start local programmes on three year olds and their families. London: DCSF.

NESS Research Team. (2012). The impact of Sure Start Local Programmes on seven year olds and their families. Research Report DFE-RR220. London: DfE. https://www.education.gov.uk/publications/eOrderingDownload/DFE-RR220.pdf.

Nutbrown, C. (2012). Foundations for quality: the independent review of early education and childcare qualifications. Final report. London: DfE. https://www.gov.uk/government/uploads/system/uploads/attachment_data/file/175463/ Nutbrown-Review.pdf.

OECD. (2014). OECD education database 2014. http://www.oecd.org/els/soc/PF3_1_Public_spending_on_childcare_and_ early_education.pdf

Sammons, P., Sylva, K., Melhuish, E., Siraj, I., Taggart, B., Smees, R., et al. (2014a). Influences on students'social-behavioural development at age 16: Effective pre-school, primary and secondary education project (EPPSE). DfE research report RR351. London: DfE. ISBN 978-1-78105-406-2.

Sammons, P., Sylva, K., Melhuish, E., Siraj, I., Taggart, B., Toth, K., et al. (2014b). Influences on students' GCSE attainment and progress at age 16: effective pre-school, primary and secondary education project (EPPSE). DfE research report RR352. London: DfE.

Sammons, P., Sylva, K., Melhuish, E. C., Siraj-Blatchford, I., Taggart, B., \& Elliot, K. (2002). The effective provision of pre-school education project, technical paper 8a: measuring the impact on children's cognitive development over the pre-school years. London: Institute of Education/DfES.

Sammons, P., Sylva, K., Melhuish, E. C., Siraj-Blatchford, I., Taggart, B., \& Elliot, K. (2003). The effective provision of pre-school education project, technical paper 8b: measuring the impact on children's social behavioural development over the preschool years. London: Institute of Education/DfES.

Sammons, P., Sylva, K., Melhuish, E., Siraj-Blatchford, I., Taggart, B., \& Hunt, S. (2008). Influences on children's attainment and progress in key stage 2: cognitive outcomes in Year 6. London: DCSF.

Sammons, P., Toth, K., Sylva, K., Melhuish, E., Siraj, I., \& Taggart, B. L. (2015a). The long-term role of the home learning environment in shaping students' academic attainment in secondary school. J Child Serv, 10, 189-201.

Sammons, P., Toth, K., Sylva, K., Melhuish, E., Siraj, I., \& Taggart, B. L. (2015b). Pre-school and early home learning effects on A-level outcomes: effective Pre-school, primary and secondary education project (EPPSE). Research Report DFE-RR472A. London: DfE.

Siraj, I., Kingston, D., \& Melhuish, E. (2015). Assessing quality in early childhood education and care: sustained shared thinking and emotional well-being (SSTEW) for 2-5 year-olds provision. London: Trentham Books.

Siraj-Blatchford, I., Sylva, K., Taggart, B., Sammons, P., Melhuish, E., \& Elliot, K. (2003). The effective provision of pre-school education (EPPE) project, technical paper 10: intensive case studies of practice across the foundation stage. London: DfEE/ Institute of Education, University of London.

Speight, S., Maisey, R., Chanfreau, J., Haywood, S., Lord, C., Hussey, D. (2015). Study of early education and development: baseline survey of families. London: DfE. http://www.seed.natcen.ac.uk/media/5645/Study_of_early_education_ and_development_survey_of_families.pdf.

Sylva, K., Melhuish, E., Sammons, P., Siraj, I., \& Taggart, B. (2004). Effective pre-school provision. London: Institute of Education.

Sylva, K., Melhuish, E., Sammons, P., Siraj, I., \& Taggart, B. (2010). Early childhood matters: evidence from the Effective preschool and primary education project. London: Routledge.

Sylva, K., Melhuish, E., Sammons, P., Siraj, I., Taggart, B., Smees, R., et al. (2014). Students' educational and developmental outcomes at age 16: Effective pre-school, primary and secondary education (EPPSE). DfE Research Report RR354. London: DfE.

Sylva, K., Melhuish, E., Sammons, P., Siraj-Blatchford, I., Taggart, B., Toth, K., et al. (2011). Effective pre-school, primary and secondary education 3-14 Project (EPPSE 3-14): final report from the key stage 3 phase: influences on students' development from age 11-14: research report, DFE RR202. London: DfE.

Sylva, K., Sammons, P., Melhuish, E. C., Siraj-Blatchford, I., \&Taggart, B. (1999). The effective provision of pre-school education project, technical paper 6a: characteristics of pre-school environments. London: Institute of Education/DfEE.

Taggart, B., Siraj-Blatchford, I., Sylva, K., Melhuish, E., \& Sammons, P. (2008). Influencing policy and practice through research on early childhood education. Int J Early Child Educ, 14, 7-21. 